\title{
Peningkatan Profesionalisme Guru Pak Melalui Pelatihan
}

\author{
Elda Br Situmorang1*, Haposan Simanjuntak², Rita Evimalinda ${ }^{3}$, Ardianto Lahagu ${ }^{4}$, \\ Lidya Dewi $S^{5}$, Rikardo Butar-Butar ${ }^{6}$, Ester Lina Situmorang ${ }^{7}$ \\ 1, 2, 3, 4, 5, 6, 7 Prodi PAK, STT REAL Batam \\ *eldasitumorang182@gmail.com
}

\begin{abstract}
This research was conducted by the author aims to determine how the influence of PAK Teacher Professionalism on Student Interest in Learning. The research was conducted using descriptive qualitative methods by interviewing several active teaching staff and browsing several books related to PAK teacher professionalism and learning interest. The results of the study show that the influence of PAK Teacher Professionalism on Student Interest in School is very large and good in meeting the development of knowledge and spiritual character of students towards Christian Religious Education.

Keywords : Christian Education teacher, Interest,Learning, Professionalism
\end{abstract}

\begin{abstract}
Abstrak
Penelitian ini di lakukan oleh penulis bertujuan untuk mengetahui bagaimana pengaruh Profesionalisme Guru PAK terhadap Minat Belajar Siswa. Penelitian dilakukan dengan metode kualitatif dekriptif dengan melakukan wawancara terhadap beberapa tenaga pengajar yang aktif dan menelusuri beberapa buku yang berkaitan dengan profesonalisme Guru PAK dan Minat Belajar. Hasil dari penelitian menunjukan pengaruh Profesionalisme Guru PAK terhadap Minat Belajar Siswa Disekolah sangat besar dan baik dalam memenuhi perkembangan pengetahuan dan karakter rohani siswa terhadap Pendidikan Agama Kristen.

Kata Kunci: Guru PAK, Minat, Pembelajaran, Profesionalisme
\end{abstract}

\section{PENDAHULUAN}

Pendidikan merupakan suatu usaha yang dilakukan secara sengaja oleh manusia yang dewasa terhadap manusia yang belum dewasa untuk menolong bertumbuh dan berkembagngnya seseorang dalam mencapai kedewasaannya. Usaha ini menunjukkan bahwa pendidikan mempunyai peran yang sangat penting dan utama dalam proses pertumbuhan dan perkembangan anak didik, sehingga anak didik mendapat dorongan, bimbingan, dan pendidikan yang jelas untuk memenuhi perkembangan sesuai usianya masing-masing.

Pendidikan Agama Kristen atau PAK (selanjutnya disingkat dengan PAK) pada hakikatnya adalah, usaha yang dilakukan secara terencana dan kontiniu dalam rangka mengembangkan kemampuan peserta didik agar dengan pertolongan Roh Kudus dapat memahami dan menghayati kasih Tuhan Allah didalam Yesus Kristus yang dinyatakan dalam kehidupan sehari-hari, terhadap sesama dan lingkungan hidupnya, yang pada dasarnya PAK dimaksudkan untuk menyampaikan kabar baik (euangelion= injil), yang disajikan dalam dua aspek, aspek Allah Tri tunggal dan karya-Nya, serta aspek nilai-nilai kristiani. ${ }^{1}$ Dengan demikian, setiap orang yang terlibat dalam proses belajar mengajar PAK memiliki keterampilan untuk mewujudkan tanda-tanda Kerajaan Allah dalam kehidupan pribadi maupun sebagai dari komunitas. Dari uraian ini terlihat bahwa PAK merupakan mata pelajaran yang prosesnya secara terencana dan berkelanjutan yang dilakukan oleh guru PAK, serta siswa sebagai peserta didik dan keterlibatan Allah Tritunggal untuk menerangi.

Sebagai bagian dari Sistem Pendidikan Nasional (Sindiknas), pelaksanan PAK sebagai dalam proses pembelajarannya disekolah-sekolah mulai dari Sekolah Dasar hingga Perguruan Tinggi pelaksanaannya dijamin oleh undang-undang. ${ }^{2} \mathrm{Hal}$ ini berarti bahwa PAK merupakan mata pelajaran yang diselenggarakan disekolah dengan menggunakan perangkat yang hampir sama dengan mata

\footnotetext{
${ }^{1}$ Sariaman Sitanggang, Bagaimana Menyusun KTSP \& Perencanaan Pembelajaran Pendidikan Agama Kristen- Tingkat Satuan Pendidikan Dasar Dan Menengah (Jakarta: Egrateia Putra Jaya, 2007).hal.55

${ }^{2}$ Dedi Hamid, Undang-Undang Nomor 20 Tahun 2003 Sistem Pendidikan Nasional (Jakarta: Durat Bahagia, 2003).hal.3
} 
pelajaran lainnya, yakni dengan melibatkan semua elemen pendidikan. Selanjutnya, untuk mencapai tujuan pembelajaran PAK di sekolah, PAK dikemas sedemikian rupa sesuai dengan keadaan lingkungan belajar. Salah satu diantaranya adalah dengan menyediakan guru PAK disekolah. Keberadaan guru PAK di sekolah tidak terlepas dari kedudukan, fungsi dan tujuan, serta tanggung jawab dan perannya sebagai pendidik profesional dengan tugas utama mendidik, mengajar, membimbing, mengarahkan, melatih, menilai, dan mengevaluasi peserta didik pada pendidikan anak usia dini jalur pendidikan formal, pendidikan dasar, dan pendidikan menengah. ${ }^{3}$ Oleh karena itu guru PAK merupakan unsur yang sangat vital dalam menjamin terlaksana serta tercapainya tujuan pembelajaran PAK disekolah. Salah satu cara yang dapat dilakukan oleh seorang guru adalah dengan memaksimalkan kinerjanya sesuai dengan perannya sebagai guru PAK. Kinerja guru PAK dalam proses pembelajaran merupakan upaya mengembangkan kegiatan yang ada menjadi kegiatan yang lebih baik, sehingga tujuan pendidikan yang telah ditetapkan dicapai dengan baik sesuai dengan target dan tujuan. Melaksanakan proses pembelajaran baik dilakukan dalam kelas maupun diluar kelas disamping mengerjakan kegiatan-kegiatan lainnya, mencakup perihal seperti: mengerjakan administrasi sekolah dan administrasi pembelajaran, melaksanakan bimbingan dan layanan pada para siswa, serta melaksanakan penilaian. ${ }^{4}$ Oleh sebab itu tugas dan fugsi guru merupakan unsur yang sangat vital dalam proses belajar mengajar sehingga sangat perlu nilai-nilai profesionalismenya ditingkatkan terus menerus.

Akan tetapi realita yang ada terkadang berbanding terbalik. Keberadaan guru yang professional terlebih Guru PAK masih sangat jauh dari apa yang dicita-citakan. Menjamurnya sekolah-sekolah yang rendah mutunya memberi suatu isyarat bahwa guru professional hanyalah sebuah wacana yang belum terealisasi secara merata dalam seluruh pendidikan yang ada di Indonesia. Hal itu menimbulkan keprihatinan yang tidak hanya datang dari kalangan akademisi, akan tetapi orang awam sekalipun ikut mengomentari ketidak beresan pendidikan dan tenaga pengajar yang ada. Ada banyak peserta didik yang mengalami ketidaknyamanan dalam belajar sehingga mengurangi minat belajarnya. Sekolah menjadi tempat yang menakutkan dan membosankan. Segogyanya sekolah merupakan salah satu lingkungan yang berpotensi besar untuk membantu peserta didik mencapai tugas perkembangan/ pembentukan karakter. Sekolah tidak hanya mendidik dalam aspek kognitif saja, tetapi juga mengembangkan aspek-aspek lainnya. Semakin kurangnya minat belajar peserta didik dalam mengikuti pelajaran Pendidikan Agama Kristen lebih dominan oleh pengaruh kurang menariknya proses belajar mengajar yang dilaksanakan. Profesionalisme guru Pendidikan Agama Kristen sangat dibutuhkan peserta didik untuk meningkatkan minat belajar siswa.

\section{METODE}

Penelitian dilakukan oleh penulis dengan menggunakan metode deskriptif kualitatif. Dimana penulisan memberikan gambaran dan interpretasi dari data-data yang telah didapatkan. Pengumpulan data dalam penelitian ini menggunakan metode observasi buku-buku yang berkaitan dengan kondisi Pendidikan Agama Kristen terhadap minat belajar siswa. Penulis melakukan penelitian dengan menyelidiki penelitian-penelitian ilmiah sebelumnya.

\section{HASIL DAN PEMBAHASAN}

Secara etimologi istilah profesi berasal dati bahasa inggris, yaitu profesion atau bahasa latin, profecus, yang atrinya mengakui, adanya pengakuan, menyatakan kemampuan atau ahli dalam melakukan suatu pekerjaan yang mempersyaratkan pendidikan tinggi bagi pelakukanya yang ditekankan pada pekerjaan mental yaitu adanya persyaratan pengetahuan teoritis sebagai instrumen untuk melekukan perbuatan praktis, bukan pekerjaan manual. ${ }^{5}$ Jadi suatu profesi harus memiliki 3 pilar pokok yaitu pengetahuan, keahlian, dan persiapan akademik.

Kata profesional berasal dari kata sifat yang arti nya pencaharian dan sebagai kata benda yg berarti orang yang mempunyai keahlian (guru, dokter, hakim dan sebagai nya). Dengan kata lain

\footnotetext{
${ }^{3}$ Undang-Undang RI No. 14 Tahun 2005 Tentang Guru Dan Dosen, n.d.

${ }^{4}$ Tabrani Rusyan, Upaya Meningkatkan Kineja Guru (Cianjur: CV. Dinamika Karya Cipta, 2000).hal.17

${ }^{5}$ Sedarwan Danim, Inovasi Pendidikan Dalam Upaya Peningkatan Profesionalisme Tenaga Kependidikan (Bandung: Pustaka Setia, 2020).hal.20
} 
pekerjaan yg bersifat professional adalah pekerjaan yang hanya dapat dilakukan oleh mereka yg khusus dipersiapkan untuk itu dan bukan pekerjaan yang dilakukan oleh mereka yang karna tidak dapat memperoleh pekerjaan lain. ${ }^{6}$

Sedangkan menurut Brian V. Hill (1990) dalam bukunya B.S. Sidjabat "Menjadi Guru Profesional" menekankan arti guru profesional adalah pribadi -pribadi yang mampu melihat dirinya sebagai orang-orang yang terlatih, mementingkan kepentingan orang lain dan taat kepada etika kerja, serta selalu siap menempatkan diri dalam memenuhi kebutuhan peserta didiknya terlebih dahulu. ${ }^{7}$

Guru Pendidikan Agama Kristen (PAK) yang professional adalah Guru Pendidikan Agama Kristen yang dalam melaksanakan tugasnya sejalan dengan tuntutan profesi, yang memiliki kemampuan atau keahlian tertentu sesuai dengan tuntutan profesinya sebagai guru agama Kristen. ${ }^{8}$

Sesuai dengan beberapa definisi diatas, maka penulis menyimpulkan bahwa guru pendidikan agama Kristen yang professional adalah guru pendidikan agama Kristen yang dapat melaksanakan tugas mengajar dan mendidik di bidang pendidikan agama Kristen dengan mengandalkan kemampuan dan karakter yang tinggi dan mengacu pada sosok Yesus Kristus sebagai Guru Agung.

Cakupan pengembangan profesi dan kompetensi yang harus dimiliki oleh guru. Cakupan pengembangan profesi guru mencakup empat bidang, yaitu:
a. kompetensi pedagogik
b. kompetensi kepribadian
c. kompetensi social dan
d. kompetensi professional. ${ }^{9}$

\section{KOMPETENSI PEDAGOGIK}

Pedagogik adalah ilmu yang membicarakan masalah atau persoalan-persoalan dalam pendidikan dan kegiatan-kegiatan mendidik, antara lain seperti tujuan pendidikan alat pendidikan, cara melaksanakan pendidikan, anak didik, pendidik dan sebagainya. Dalam standar Nasional pendidikan, penjelasan Pasal 28 ayat (3) butir a dikemukakan bahwa kompetensi pedagogic adalah Kemampuan mengelola pembelajaran peserta didik yang meliputi pemahaman terhadap peserta didik, perancangan dan pelaksanaan pembelajaran, pelaksanaan pembelajaran, yang mendidik dan dialogis, pemanfaat teknologi pembelajaran, evaluasi hasil belajar, dan pengembangan peserta didik untuk mengaktualisasikan berbagai potensi yang dimilikinya. ${ }^{10}$

Kompetensi pedagogik ini, guru wajib untuk memahami dan memiliki kompetensi ini sebagai dasar terhadap proses pendidikan. Secara rinci setiap subkompetensi dijabarkan menjadi indicator esensial sebagai berikut ini :

1. Guru memahami peserta didik secara mendalam memiliki indicator esensial: memahami peserta didik dengan memanfaatkan prinsip-prinsip perkembangan kognitif; memahami peserta didik dengan memanfaatkan prinsip-prinsip kepribadian; dan mengidentifikasi bekal ajar awal peserta didik.

2. Guru merancang pembelajaran, termasuk memahami landasan pendidikan untuk kepentingan pembelajaran. Memahami landasan pendidikan, menerapkan teori belajar dan pembelajaran, menentukan strategi pembelajaran berdasarkan karakteristik peserta didik, kompetensi yang ingin di capai, dan materi ajar, serta menyusun rancangan pembelajaran berdasarkan strategi yang dipilih.

3. Guru melaksanakan pembelajaran: menata latar (setting) pembelajaran, dan melaksanakan pembelajaran yang kognitif.

4. Merancang dan melaksanakan evaluasi pembelajaran memiliki indicator esensial: merancang dan melaksanakan evaluasi (assessment) proses dan hasil belajar secara berkeseimbangan dengan metode berbagai metode; menganalisis hasil evaluasi proses dan hasil belajar untuk menentukan

\footnotetext{
${ }^{6}$ Uzer Usman, Menjadi Guru Profesional (Jakarta: Remaja Rosda Karya, 2017).hal.14

${ }^{7}$ B.S.Sijabat, Menjadi Guru Profesional (Bandung: Yayasan Kalam Hidup, 2000).hal 34

${ }^{8}$ Lidya Yulianti, Profesionalisme, Standar Kompetensi, Dan Pengembangan Profesi Guru PAK (Pendidikan Agama Kristen) (Jakarta: Bina Media Informasi, 2009).hal.15

${ }^{9}$ Undang-Undang RI No. 14 Tahun 2005 Tentang Guru Dan Dosen.

${ }^{10}$ E Mulyasa, Standar Kompetensi Dan Sertifikasi Guru (Bandung: Remaja Rosdakarya, 2007).hal.75
} 
tingkat ketuntasan belajar (mastery learning); dan memanfaatkan hasil penilaian pembelajaran untuk perbaikan kualitas program pembelajaran secara umum.

5. Guru mengembangkan peserta didik untuk mengaktualisasikan berbagai potensi yang dimilikinya: memfasilitasi peserta didik untuk mengembangkan berbagai potensi akademik; dan memfasilitasi peserta didik untuk mengembangkan berbagai potensi non akademik.

\section{MINAT BELAJAR}

Dalam kegiatan belajar mengajar di sekolah, salah satu keberhasilan belajar yang harus dimiliki seorang siswa adalah tidak terlepas dengan adanya minat anak yang sungguh-sungguh terhadap suatu pelajaran. Minat sangat besar dari penyataan senang atau tidaknya seseorang terhadap suatu objek tertentu. Minat adalah suatu rasa yang lebih suka dan rasa keterikatan pada suatu hal atau aktifitas tanpa ada yang menyuruh. Minat pada dasarnya adalah penerimaan akan suatu hubungan antara diri sendiri dengan sesuatu di luar dirinya. Semakin kuat atau dekat hubungan tersebut semakin besar minatnya. ${ }^{11}$

Dalam kutipan diatas dapat dikatakan bahwa minat dapat diekspresikan melalui suatu pernyataan yang menunjukkan bahwa seseorang lebih menyukai sesuatu hal dari pada hal lainnya, dan dapat pula di manifestasikan melalui partisipasi dalam suatu aktifias, siswa yang memiliki minat terhadap suatu subjek tertentu cenderung untuk memberikan perhatian yang lebih besar terhadap subjek tersebut. Dalam menekuni suatu pekerjaan atau kegiatan factor minat adalah merupakan suatu hal penting. Minat yang dimiliki seseorang pada dasarnya turut menentukan behasil tidaknya untuk melaksanakan suatu kegiatan. Salah satu usaha untuk membimbing perhatian anak didik yaitu pemberian rangsangan yang menarik perhatisn siswa. Dengan adanya rangsangan maka minat seseorang terdorong untuk memperhatikan dan melakukan sesuatu hal. Demikian juga halnya dalam belajar bahwa minat merupakan suatu hal yang sangat penting. Dengan adanya minat untuk belajar maka dapat menimbulkan perhatian yang serius untuk mempelajarinya.

Dari kutipan diatas bahwa perhatian terpusat hanya tertuju terhadap hal-hal yang diminati, yaitu pada suatu objek tertentu, misalnya jika seorang siswa sedang belajar maka perhatianya hanya tertuju terhadap pelajaranya. Jadi apabila seorang siswa tidak menarik perhatianya terhadap sesuatu, maka tidak dianggap penting baaginya dan akan mudah melupakanya. Jadi dalam kegiatan belajar seseorang hendaknya menggunakan perhatian dan terpusat pada pelajaranya. Sehingga pelajaran yang di terimanya dapat di pahami dengan baik. Siswa yang meminati suatu hal akan terikat perhatiannya dan tertarik untuk mengulangi apa yang ia minati. Dengan demikian untuk melaksanakan aktifitas belajarnya juga dapat di nikmati dan hasil prestasi yang dicapai akan memuaskan. Belajar dan minat sama-sama saling melengkapi atau mempunyai hubungan yang erat dan saling mendukung terhadap keperibadian seseorang. Dewa Ketut Sukardi mengatakan: Bidang studi yang menarik minat seseorang akan dapat di pelajari dengan sebaik baiknya, dan sebaliknya bidang studi yang tidak sesuai dengan minatnya tidak akan mempunyai daya tarik baginya. ${ }^{12}$ Maka dari itu dalam kegiatan belajar di harapkan adalah minat yang di dasari oleh bakat yang kemudian di kembangkan secara maksimal dan di tunjang oleh fasilitas yang di harapkan. Secara umum pemahaman orang terhadap minat adalah kemauan, dorongan hati ataupun keinginan hati untuk memiliki hal yang merupakan suatu aktifitas yang dipilih secara bebas oleh individu sesuai dengan kebutuhannya. Poerwadarminta mengatakan: "Minat adalah kecenderungan hati yang tinggi terhadap suatu keinginan.

\section{ASPEK-ASPEK MINAT}

Dari semua pengertian minat yang telah dikemukakan di atas maka dapat kita lihat beberapa aspek yang ada pada minat. Slameto mengatakan, aspek-aspek minat antara lain perhatian, motivasi, dan keinginan yang menjadi indicator.

Aspek-aspek tersebut secara rinci akan diuraikan satu persatu, yakni sebagai berikut:

\section{Perhatian}

\footnotetext{
${ }^{11}$ Slameto, Belajar Dan Faktor-Faktor Mempengaruhinya (Jakarta: Rineka Cipta, 1991).hal.182

12 Dewa Ketut Sukardi, , Kemandirian Belajar, (Bandung: Rosdakarya, 2001), Hal 182 (Bandung: Remaja Rosda karya, 2001).hal.182
} 
Menurut Slameto yang mengatakan bahwa perhatian adalah: "keaktifan jiwa yang tinggi, yang tertuju terhadap suatu objek (benda) atau sekelompok objek." ${ }^{\prime 3}$ Dari pendapat ini maka dapat dikatakan bahwa perhatian itu merupakan suatu perbuatan yang sifatnya aktif yang tertuju pada suatu objek, apabila hal ini kita aplikasikan dengan soal belajar maka implementasinya adalah bahwa perhatian itu merupakan suatu perbuatan yang terpusat untuk belajar atau pun mengikuti pelajaran. Sejalan dengan hal itu Kartini Kartono mengatakan: "siswa yang memiliki minat terhadap suatu subjek tertentu cenderung untuk memberikan perhatian yang lebih besar terhadap subjek tersebut. ${ }^{14}$ Dari pendapat ini maka dapat disimpulkan bahwa apabila seseorang itu memiliki minatmaka ia akan memberikan perhatian yang cukup besar terhadap apa yang diminati itu, sehingga jelas bahwa perhatian itu mempunyai keterikatan dengan masalah minat belajar.

\section{Motivasi}

Menurut Mc. Donald dalam Wasti Soemanto, memberikan defenisi tentang motivasi yaitu, "suatu perubahan tenaga dalam diri pribadi seseorang yang ditandai oleh dorongan efektif dan reaksireaksi dalam usaha mencapai tujuan. ${ }^{15}$ Dari kutipan ini dapat disimpulkan motivasi merupakan pendorong bagi perbuatan seseorang. Hal ini menyangkut bahwa seseorang dapat berbuat demikian. Begitu juga dalam belajar pengaruh motivasi dalam belajar akan membuat reaksi-reaksi yang mengarahkan dirinya kepada usaha-usaha untuk memperoleh hasil yang baik.

\section{Keinginan}

Menurut W.J.S. Poerwardinata mengatakan bahwa keinginan adalah, "adaya hasrat seseorang untuk mengetahui dan mengerti sesuatu." ${ }^{\text {"16 }}$ Maka dari kutipan ini dapat dikatakan dengan keinginan di dalam belajar, maka isi pelajaran itu akan mudah di mengerti. Sejalan dengan hal tersebut Agus Sujanto mengatakan bahwa keinginan adalah, "dorongan nafsu yang tertuju kepada sesuatu benda tertentu atau yang konkret." ${ }^{17}$ Dari kutipan ini jelas di katakan bahwa keinginan merupakan dorongan yang timbul dari perasaan hati selanjutnya akan timbul perhatian terhadap objek yang dilihat.

Agus Sujanto menyatakan bahwa, "kecenderungan adalah hasrat yang aktif yang menyuruh kita agar cepat bertindak. ${ }^{18}$ Jadi kecenderungan itu merupakan suatu sikap condong untuk melakukan perbuatan yang aktif kepada suatu objek dengan sikap kecenderungan itu, maka sikap siswa akan nampak ke arah mana kesukaan hatinya.

a. Faktor-Faktor Yang Mempengaruhi Minat Belajar

Minat bagi manusia merupkan motor penggerak terhadap sumber daya jiwanya, oleh karena itu minat belajar merupakan faktor yang terpenting dalam proses belajar mengajar. Walaupun seluruhnya bahan itu diminati siswa, bahkan kalau diperhatikan jauh lebih banyak bahan pelajaran yang diberikan di sekolah itu tidak menarik siswa.

b. Usaha-Usaha Untuk Meningkatkan Minat Belajar Siswa

Guru harus selalu berusaha untuk meningkatkan minat belajar siswa. Hal ini sesuai dengan pendapat W.S. Winkel yang mengatakan, "masalah pokok yang perlu dihayati oleh guru atau pengajar adalah bagaimana meningkatkan minat, perhatian murid atau subjek belajar terhadap bahan pelajaran yang dipelajarinya. ${ }^{19}$

Dari pendapat tersebut jelaslah bahwa guru mempunyai suatu tugas untuk selalu melakukan upaya-upaya untuk meningkatkan minat belajar agar dengan demikian tujuan yang diharapkan dapat tercapai. Thamrin Nasution menguraikan usaha guru PAK dalam meningkatkan minat belajar siswa yakni sebagai berikut:

1. Guru PAK berusaha meningkatkan disiplin para siswa

2. Guru PAK berusaha membantu masalah yang dihadapi siswa, dalam menyongsong masa depan yang lebih baik.

\footnotetext{
${ }^{13}$ Slameto, Belajar Dan Faktor-Faktor Mempengaruhinya.hal.58

${ }^{14}$ Kartini Kartono, Teori Kepribadian (Bandung: Kalam Kudus, 1986).hal.82

${ }^{15}$ Wasti Sumanto, Psikologi Pendidikan (Jakarta: Bina Aksara, 1996).hal.191

16 “Kamus Besar Bahasa Indonesia," KBBI WEB, https://kbbi.web.id/.

${ }^{17}$ Agus Sujanto, Psikologi Umum (Jakarta: Bumi Aksara, 2012).hal.86

${ }^{18}$ Ibid.hal.86

${ }^{19}$ W.S. Winkel, Psikologi Pengajaran (Yogyakarta: Media Abadi, 2007).hal.35
} 
3. Guru PAK berusaha meningkatkan perkembangan pengetahuan siswa. ${ }^{20}$

Pada hakikatnya Pendidikan Agama Kristen di sekolah akan berusaha untuk mengembangkan pengetahuan siswa dengan agama sebagai bekal mereka di masa yang akan datang siswa dapat membekali dirinya dengan berbahagia. Ilmu pengetahuan sekaligus mengajarkan Firman Tuhan harus mampu mengembangkan sesuai dengan pengetahuan dasar siswa.

\section{SIMPULAN}

Berdasarkan uraian yang telah dikemukakan dapat di simpulkan bahwa, dengan mengembangkan Profesioalisme guru dalam mengajar dapat berpengaruh kepada minat belajar siswa, berperan penting untuk mengacu kepada pembentukan minat belajar siswa yang lebih baik. Dalam setiap proses pembelajaran profesionalisme guru sangat berpengaruh dalam mengembangkan minat belajar siswa. Karena guru PAK memiliki peran penting bagi masa depan anak didik dan guru memiliki tanggung jawab dalam mengajar. Guru professional harus menyadari keprofesionalan guru yang maksimal, untuk mengembangkan minat belajar siswa. Guru PAK sangat mempengaruhi factorfaktor karakteristik siswa, jika siswa tidak memiliki pengajaran akan kebenaran Firman Tuhan disekolah maka dapat mengakibatkan karakteristik siswa kurang baik. Guru PAK harus mampu mengembangkan pengetahuan siswa terhadap Pendidikan Agama Kristen. Maka jika guru PAK tidak memiliki profesinalisme dalam mengajar maka akan berpengaruh terhadap minat belajar siswa. Maka sangat dibutuhkan Profesinalisme Guru PAK dalam mengajar untuk meningkatkan minat belajar siswa.

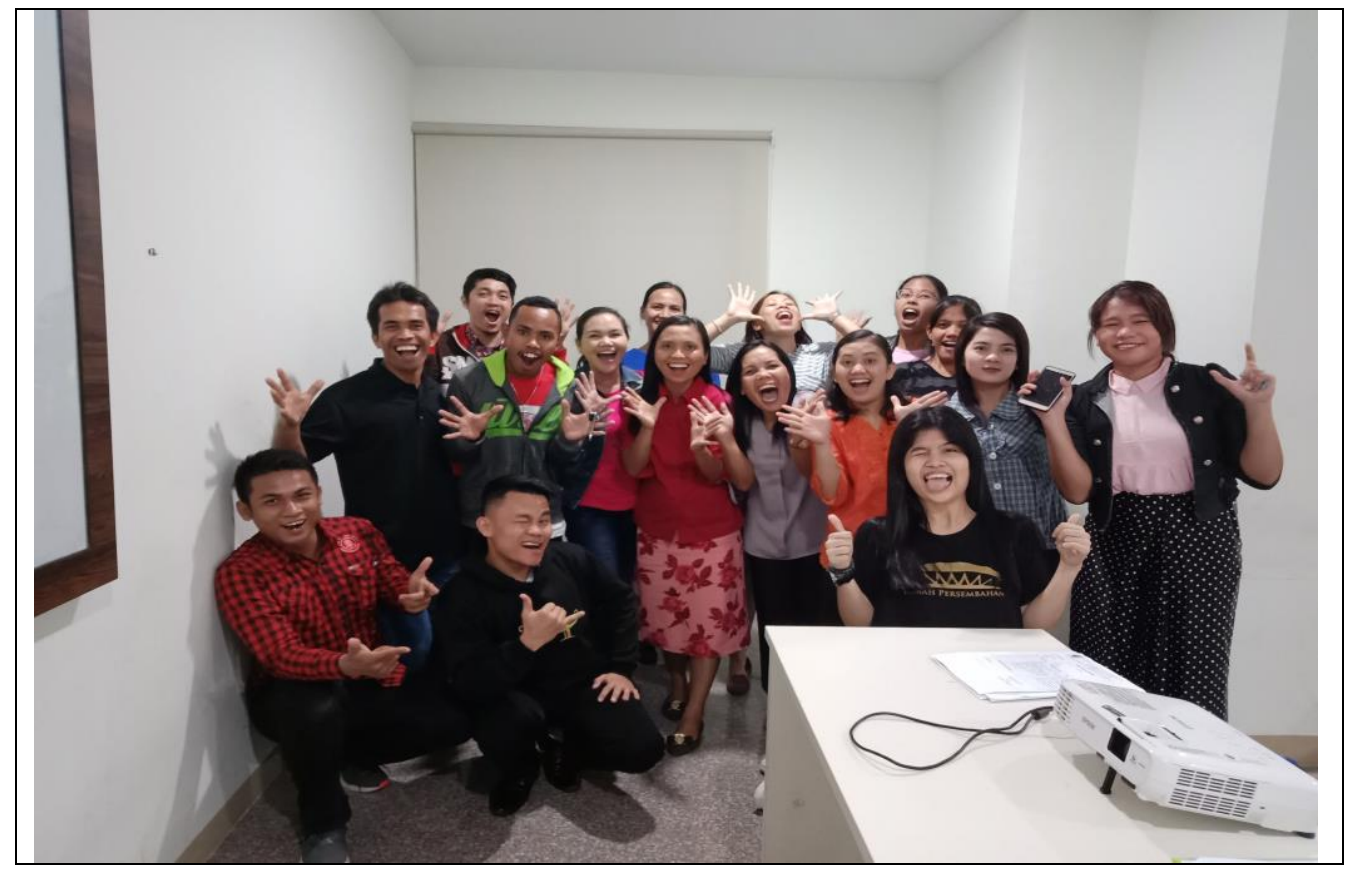

Gambar 1. Pelatihan Bersama Guru-Guru PAK Batam

\section{DAFTAR PUSTAKA}

B.S.Sijabat. Menjadi Guru Profesional. Bandung: Yayasan Kalam Hidup, 2000.

Danim, Sedarwan. Inovasi Pendidikan Dalam Upaya Peningkatan Profesionalisme Tenaga Kependidikan. Bandung: Pustaka Setia, 2020.

Hamid, Dedi. Undang-Undang Nomor 20 Tahun 2003 Sistem Pendidikan Nasional. Jakarta: Durat Bahagia, 2003.

Kartono, Kartini. Teori Kepribadian. Bandung: Kalam Kudus, 1986.

Mulyasa, E. Standar Kompetensi Dan Sertifikasi Guru. Bandung: Remaja Rosdakarya, 2007.

Nasution, Thamrin. Membangkitkan Minat Belajar Anak. Jakarta: Madju, 1994.

Rusyan, Tabrani. Upaya Meningkatkan Kineja Guru. Cianjur: CV. Dinamika Karya Cipta, 2000.

20 Thamrin Nasution, Membangkitkan Minat Belajar Anak (Jakarta: Madju, 1994).hal.39 
Sitanggang, Sariaman. Bagaimana Menyusun KTSP \& Perencanaan Pembelajaran Pendidikan Agama Kristen- Tingkat Satuan Pendidikan Dasar Dan Menengah. Jakarta: Egrateia Putra Jaya, 2007.

Slameto. Belajar Dan Faktor-Faktor Mempengaruhinya. Jakarta: Rineka Cipta, 1991.

Sujanto, Agus. Psikologi Umum. Jakarta: Bumi Aksara, 2012.

Sukardi, Dewa Ketut. , Kemandirian Belajar, (Bandung: Rosdakarya, 2001), Hal 182. Bandung: Remaja Rosda karya, 2001.

Sumanto, Wasti. Psikologi Pendidikan. Jakarta: Bina Aksara, 1996.

Usman, Uzer. Menjadi Guru Profesional. Jakarta: Remaja Rosda Karya, 2017.

Winkel, W.S. Psikologi Pengajaran. Yogyakarta: Media Abadi, 2007.

Yulianti, Lidya. Profesionalisme, Standar Kompetensi, Dan Pengembangan Profesi Guru PAK (Pendidikan Agama Kristen). Jakarta: Bina Media Informasi, 2009.

"Kamus Besar Bahasa Indonesia." KBBI WEB. https://kbbi.web.id/.

Undang-Undang RI No. 14 Tahun 2005 Tentang Guru Dan Dosen, n.d. 